\title{
The Huge Burden of Infertility in India- Are We Crumbling Underneath?
}

\author{
Sabahat Rasool* and Omar Salim Akhtar \\ Fertility Consultant \& Reproductive Medicine Specialist, Mumbai \\ Urologist \& Andrologist, Government Medical College, India
}

Submission: June 12, 2018; Published: August 09, 2018

*Corresponding author: Sabahat Rasool, MD, MRCOG (UK), DNB, MNAMS, FMAS, Fertility Consultant \& Reproductive Medicine Specialist, Mumbai, India; Email: sabahatrasool@yahoo.co.in

\section{Abstract}

Though a matter of varying sensitivities and urgency, procreation is a dream of everybody. According to studies, the need for parenthood is greatest in India but awareness of fertility problems is lowest. In societies like India's, parenthood is a matter of utmost importance and urgency, and inability to conceive leads to stigmatization, ostracism and social distress, the burden of which falls disproportionately on women even when the cause lurks in their male partners [1]. Childlessness leads to maternal \& reproductive health problems like violence against women, exploitation, and divorces are significantly higher in infertile women [2]. There is a hush-hush surrounding this social stigma, and more public awareness about fertility issues and the treatments available to help is needed. Affordability, availability, access, awareness and assurance are the key barriers limiting the correct diagnosis and appropriate treatment of infertility in India.

Keywords: Parenthood; Infertile women; Fertility; Unprotected sexual; Fertility rate; Contraceptives; Pregnancy; Lifestyle; Sedentary lifestyle; Tobacco consumption; Polycystic ovary syndrome; Pelvic infections; In-vitro fertilization; Stigmatization; Awareness; Delay pregnancy; Wedlock; Infertile couples; Artificial gametes; Assisted reproduction; Maternal \& reproductive health problems

Abbreviations: WHO: World Health Organization; PCOS: Polycystic Ovary Syndrome; IVF: In-Vitro Fertilization

\section{Mini Review}

The good news is that around $90 \%$ of infertility issues are treatable. The success stories of Assisted Reproduction are getting bigger and bigger. We are on the verge of making artificial gametes. The bad news is that the burden of infertility (not able to get pregnant after 12 or more months of regular unprotected sexual intercourse) is high. The World Health Organization (WHO) states that one in every 4 couples in developing nations is affected by infertility [3]. India has 22-23 million infertile couples, and the total fertility rate, which is the number of children who would be born per woman if she were to pass through the childbearing years bearing children according to a current schedule of age-specific fertility rates, has declined from 3.9 in 1990s to 2.3 in 2013 [4]. On the contrary, the use of contraceptives has increased from $45 \%$ in 1988 to around 59\% in 2015. The expected prevalence of contraceptive use is expected to further rise to $63 \%$ in 2020 .

In the past, women would get married at the age of 16 to 18 years or even earlier and complete their families by the age of 25 to 26 years! Hence sexual activity happened in wedlock within the most fertile period of their lives. Today the scene is totally different and alarming! There is a marked deterioration of risk factors for infertility. Age at marriage and first pregnancy has risen. Lifestyle changes have gone from bad to worse, and include increasing age at marriage, increasing number of working women who delay pregnancy, rising alcohol and tobacco consumption, sedentary lifestyle coupled with fast food consumption, and disturbing levels of obesity. More educated women are more likely to postpone marriages and childbirth. They also likely to opt for smaller family size as they are busy with their careers and work commitments. The prevalence of smoking among Indian men is around 48\%, which is way higher than that in the UK and the US. Smoking is known to lower the sperm count, motility as well as function $[5,6]$.

To make things even worse, Polycystic Ovary Syndrome (PCOS), tuberculosis, and pelvic infections have been on a rise [7]. The global prevalence of PCOS ranges between 5-10\%. However, the prevalence is Indian subcontinent has been estimated to be between 4 to $25 \%$ in various studies [8]. As far as the ovarian reserve of a woman is concerned, it is well known that Asian women are lower in their reserves compared to Caucasians. This boils down to reduced fertility at younger ages [9]. It is disheartening to know that only $1 \%$ of infertile couples in India 


\section{Global Journal of Reproductive Medicine}

are seeking fertility treatment. This may be attributed to low awareness and accessibility issues, high cost and unacceptability. Even in the metropolitans like Mumbai and Delhi, the demand for fertility treatment is 9 to 12 times higher than the current market. The dismal state of low penetration of infertility treatments is adding fuel to the fire. There is a small pool of IVF specialists and trained embryologists in the country. From a pool of around 25,000 gynecologists, only around 1000 are performing the actual IVF procedures. At present, the estimated number of in-vitro fertilization cycles countrywide are around 1,00,000 and it is expected to touch 2,50,000 and above by the year 2020. An average IVF cycle costs between 1,00,000 and 1,25,000 Indian Rupees [10]. Despite the treatment cost being 3-4 times lower compared to the US, treatment is affordable to only $20 \%$ of the general population. The low income-group patients form a major chunk as they are more driven be family pressures and stigmatization. None of the insurance programs and only a handful of public hospitals offer IVF.

We must focus on creating national awareness through patient education at a war footing. There is an urgent unmet need to include fertility treatments in comprehensive reproductive health care and insurance programs and to explore public-private partnerships to increase the penetrance of fertility treatments. The skill gap has to be bridged to deliver high-quality care by increasing the pool of trained IVF specialists, and as the field of reproductive medicine is growing by leaps and bounds, making sure that the treating physicians are abreast with the latest evidence-based medicine.

\section{References}

1. Unisa S (1999) Childlessness in Andhra Pradesh, India: Treatment seeking and Consequences. Reproductive Health Matters 7(13): 54-65.

2. Pearce TO (1999) She will not be listened to in Public: Perceptions among the Yoruba of Infertility and Childlessness in Women. Reproductive Health Matters 7: 69-79.

3. http://www.who.int/nmh/publications/ncd-status-report-2014/en/

4. http://rchiips.org/NFHS/factsheet_NFHS-4.shtml

5. Giovino GA, Mirza SA, Samet JM, Gupta PC, Jarvis MJ, et al. (2012) Tobacco use in 3 billion individuals from 16 countries: An analysis of nationally representative cross-sectional household surveys. Lancet 380(9842): 668-679.

6. (2015) WHO global report on trends in prevalence of tobacco smoking 2015. Geneva, Switzerland.

7. Ghosh K, Ghosh K, Chowdhury JR (2011) Tuberculosis and female reproductive health. J Postgrad Med 57(4): 307-313.

8. Nidhi R, Padmalatha V, Nagarathna R, Amritanshu R (2011) Prevalence of polycystic ovary syndrome in Indian adolescents. J Paedtr Adoles Gynecol 24(4): 223-227.

9. Iglesias C, Banker M, Mahajan N, Herrero L, Meseguer M, et al. (2014) Ethnicity as a determinant of ovarian reserve: differences in ovarian aging between Spanish and Indian women. Fertil Steril 102(1): 244249.

10. (2015) Call for Action: Expanding IVF treatment in India. EY Analysis.
Your next submission with Juniper Publishers will reach you the below assets

- Quality Editorial service

- Swift Peer Review

- Reprints availability

- E-prints Service

- Manuscript Podcast for convenient understanding

- Global attainment for your research

- Manuscript accessibility in different formats (Pdf, E-pub, Full Text, Audio)

- Unceasing customer service

Track the below URL for one-step submission https://juniperpublishers.com/online-submission.php 